\title{
A new chapter for Fisheries and Aquatic Sciences as we re-launch with BioMed Central
}

\author{
Sungchul C. Bai®
}

We are proud to re-launch an open access journal through BioMed Central, entitled Fisheries and Aquatic Sciences (FAS) (http://fas.biomedcentral.com), the official English Journal of the Korean Society of Fisheries and Aquatic Science (KOSFAS), listed SCOPUS since 2014. All articles published in the journal since 2009 are indexed in SCOPUS. The first articles of FAS in 2009 (volume 12, no 2) cover the topics of seafood processing (Park et al. 2009a; Park et al. 2009b), fish genetics (Lee et al. 2009), seaweed culture (Wan et al. 2009), fish feed and nutrition (Kim et al. 2009), fish disease and prevention (Kosuke et al. 2009), sustainable shellfish farm management (Jeong et al. 2009a; Jeong et al. 2009b), and sustainable fisheries management in Korean waters (Oh et al. 2009; Hwangbo et al. 2009) and we have continued publishing on these topics ever since.

KOSFAS formed in 2009 as a result of a merger between two of the largest and long-running societies in this field, the Korean Society of Fisheries Science (KOSFS) and the Korean Society of Aquaculture. Originally launched in 1998 by KOSFS as their first English Language journal, the Journal of Fisheries and Technology was renamed to Fisheries and Aquatic Sciences in 2009 to coincide with the newly formed society.

FAS is one of the top journals in the field of fisheries and aquaculture sciences in the Rep. of Korea (ROK) and it has been well recognized by not only a domestic audience but also the international readers and researchers. An impact factor (IF) for FAS would be available from SCOPUS in March 2017. However an impact factor for FAS was listed as 0.35 by the official report of Korean Research Foundation (2015), and an unofficial impact factor of 0.832 has been calculated by the society.

We at KOSFAS look forward to working with BioMed Central to promote Fisheries and Aquatic Sciences

Correspondence: scbai@pknu.ac.kr

Pukyong National University, Busan City, Republic of Korea worldwide as an international open access journal in the field of fisheries and aquaculture.

As the Human population continues to increase, as does the demand for seafood. With the exception of a handful of marine species, the only way to meet these demands is by capture fisheries production, as more natural production methods are limited and not sustainable. The Food and Agriculture Organization of the United Nations (FAO) reported that global capture fisheries and aquaculture production in 2013 were 92.6 and 97.2 (million $\mathrm{mt}$ ) respectively (FAO, 2015). Aquaculture now provides more than $50 \%$ of consumable aquatic products, accounting for almost half of worlds fish supply. Aquaculture is at present the only growing sector within the fishing industry and is also reputed as the fastest growing food production sector in the world. Aquaculture is also a very important and well-established sector in Korea, providing food security, revenue and employment to the country. Blessed with an abundance of fisheries resources, Koreans have developed the distinct fish-eating culture based on marine products. Not surprisingly, according to the report of Korea Maritime Institute, per capita seafood consumption reached $53.9 \mathrm{~kg} /$ year (finfish $22.4 \mathrm{~kg}$, shellfish $16.0 \mathrm{~kg}$ and seaweed $15.6 \mathrm{~kg}$ ) in 2014 (Bai et al. 2015). Since Korea has a coastline of $2,413 \mathrm{~km}$ (ROK only) and an archipelago of 3,000 islands, fishing has always been a national industry of major economic importance.

Stagnated capture production in recent years has led the country to increase its focus on aquaculture. Fortunately, the developing technology coupled with a solid foundation of Korean aquaculture has enabled us to bridge the gap between the demand and supply of seafood. Aquaculture in Korea has expanded, intensified and rapidly diversified in the last four decades. In the 1960s and 1970s, aquaculture technology was mainly developed to produce seedlings of laver, oysters, etc., while by the 1980 s, it was devoted to shellfish. In the 1990s 
and 2000s it was dedicated to promoting the pen and cage systems for finfish culture, and now, the integration and sustainable high technology has gained momentum for the future. In 2014, mariculture is the highest contributor $(1,546,980$ tons) to total aquaculture production $(1,567,737$ tons), and it accounts to $98 \%$ of the total aquaculture production. The Korean peninsula is home to various algal species and marine seaweeds that have been the integral part of aquaculture (Bai et al. 2015). The production volume of the Republic of Korea is dominated by seaweeds and ranked 4th among top eight world seaweed producing countries in 2013, producing over 1 million tons (FAO, 2015).

Therefore, we believe that putting the seafood at the center of the journal is unique and will serve both researchers and our general readers. Fisheries and Aquatic Sciences intends to treat different topics of fisheries and aquatic sciences including but not limited to: aquaculture, fish diseases, aquatic life and environments, fisheries, seafood sciences and marine biotechnology. At the same time there is a growing awareness among both producers and consumers on the topics of responsible and sustainable fisheries and on the impact of climate change for fisheries and aquaculture. We are interested in publishing articles of high quality and novelty, but we also consider research results of more general interest and international issues not only from the scientific communities but also from the relevant industries.

BioMed Central and KOSFAS has been working hard for the last few months to publish the first FAS articles in 2016 and these first articles will cover the topics on fish reproduction physiology (Mahmud et al. 2016), fish nutrition (Yun et al. 2016), fish disease (Lee et al. 2016), and analytical chemistry in food sciences (Kim et al. 2016). Fisheries and Aquatic Sciences will continue to publish articles on these topics and more as part of BioMed Central. Fisheries and Aquatic Sciences benefits from an editorial board of over 53 highly specialized members from 13 different countries.

Received: 2 February 2016 Accepted: 16 February 2016

Published online: 11 March 2016

\section{References}

Bai SC, Taddese F, Lee SH, Seong MJ. Outlook for Korean Aquaculture. Aquainfo. 2015;3(1):20-41.

FAO. FAO Global Capture Production database updated to 2013 - Summary information. 2015. FAO (http://www.fao.org/3/a-i4883e.pdf).

Hwangbo Y, Lee DJ, Lee Y-W, Lee K. The Frequency and Length Dependence of the Target Strength of the Largehead Hairtail (Trichiurus lepturus) in Korean Waters. Fish Aqua Sci. 2009:12(2):152-61.

Jeong WG, Cho S-M, Lee SJ. Studies for the Sustainable Management of Oyster Farms in Pukman Bay, Korea: Estimate of Primary Production. Fish Aqua Sci. 2009a;12(2):111-7.

Jeong WG, Cho S-M, Lee SJ. Studies for the Sustainable Management of Oyster Farms in Pukman Bay, Korea: Estimation of Carrying Capacity from Food Availability. Fish Aqua Sci. 2009b;12(2):118-29.

Kim K-D, Kang YJ, Moon Lee HY, Kim K-W, Son MH. Effects of Protein and Lipid Levels in Extruded Pellets on the Growth and Body Composition of the Olive
Flounder (Paralichthys olivaceus) during the Summer and Winter Seasons. Fish Aqua Sci. 2009:12(2):104-10.

Kim J, Um M, Han D, Kim I, Lee C, Kim Y, Yang H, Yoon M, Kim Y, Kim J and Cho S: Method development and validation for dieckol in the standardization of phlorotannin preparations. Fish Aqua Sci 2016;19(1).

Korean Research Foundation. Journal Citation Report, Korea Citation Index 2015; (https:// www.kci.go.kr/kciportal/po/search/poCitaView.kci?sereld=000404\&year=2013=en).

Kosuke Z, Lee SY, Kim KH, Nam YK. Functional Evaluation of the Rockbream (Oplegnathus fasciatus) Beta-actin Promoter as a Candidate Regulatory Element for DNA Vaccination. Fish Aqua Sci. 2009;12(2):98-103.

Lee SY, Kim KH, Nam YK. Molecular Characterization of Rockbream (Oplegnathus fasciatus) Cytoskeletal $\beta$-actin Gene and Its 5'-Upstream Regulatory Region. Fish Aqua Sci. 2009;12(2):90-7.

Lee J-H, Lee J-G, Zeon S-R, Park K-I and Park KH: Methods to eradicate soft tunic syndrome (STS)-causing protozoa Azumiobodo hoyamushi, the highly infectious parasite from tunicate Halocynthia roretzi. Fish Aqua Sci 2016, 19(1).

Mahmud NA, Hafizur Rahman HM, Mostakim GM, Quader Khan MG, Shahjahan Md, Lucky NS and Sadiqul Islam M: Cyclic variations of gonad development of striped snakehead Channa striata in the lentic and lotic environments. Fish Aqua Sci 2016;19(1).

Oh C-W, Kim ST, Na J-H. Variations in Species Composition, Biomass, and Density in Shrimp Trawl Bycatch Across Seasons and Tidal Phases in Southern Korean Waters: Developing a Fisheries Risk Management Approach. Fish Aqua Sci. 2009:12(2):138-51.

Park CH, Kim HJ, Kang KT, Park JW, Kim J-S. Fractionation and Angiotensin Iconverting Enzyme (ACE) Inhibitory Activity of Gelatin Hydrolysates from by-products of Alaska Pollock Surimi. Fish Aqua Sci. 2009a;12(2):79-85.

Park HJ, Kim HR, Choi JS. Antioxidant Effects of 2,3,6-tribromo-4,5dihydroxybenzyl Methyl Ether (TDB) from the Red Alga, Symphyocladia latiuscula. Fish Aqua Sci. 2009b;12(2):86-9.

Wan XQ, Park HH, Yoo HI, Choi HG. Temporal Variation in Seaweed Biomass and Coverage in Korean Coasts: Ongdo, Chungnam. Fish Aqua Sci. 2009;12(2): 130-7.

Yun H, Park G, Ok I, Katya K, Hung Silas and Bai SC: Determination of the dietary lysine requirement by measuring plasma free lysine concentrations in rainbow trout Oncorhynchus mykiss after dorsal aorta cannulation. Fish Aqua Sci 2016;19(1).

Submit your next manuscript to BioMed Central and we will help you at every step:

- We accept pre-submission inquiries

- Our selector tool helps you to find the most relevant journal

- We provide round the clock customer support

- Convenient online submission

- Thorough peer review

- Inclusion in PubMed and all major indexing services

- Maximum visibility for your research

Submit your manuscript at www.biomedcentral.com/submit
Biomed Central 